\title{
Hastaların Hemşirelik Bakım Memnuniyetleri: Cerrahi Hastaları Örneği
}

\section{Nursing Care Satisfaction of Patients: Surgical Patients Example}

\author{
Sibel Arslan ${ }^{1}$ (D) Ayla Gürsoy ${ }^{2}$ \\ ${ }^{1}$ Kilis 7 Aralık Üniversitesi Yusuf Şerefoğlu Sağlık Bilimleri Fakültesi, Cerrahi Hastalıklar Hemşireliği Anabilim Dalı, Kilis, TÜRKiYE \\ ${ }^{2}$ Antalya Bilim Üniversitesi Sağlık Bilimleri Fakültesi, Hemşirelik Bölümü, Antalya, TÜRKIYYE
}

Geliş tarihi/ Date of receipt: 07/12/2020 Kabul tarihi/ Date of acceptance: 09/04/2021

(c) Ordu University Faculty of Health Sciences, Department of Nursing, Turkey, Published online: 18/04/2021

\section{ÖZ}

Amaç: Araştırma cerrahi servislerindeki hastaların hemşirelik bakım memnuniyetlerini ölçmek amacıyla yapıldı.

Yöntem: Tanımlayıcı türde olan araştırma cerrahi servislerinde 267 hasta ile gerçekleştirildi. Veriler "hasta tanıtıcı özellikler formu" ve "Newcastle hemşirelik bakımı memnuniyet ölçeği" kullanılarak yüz yüze görüşme yöntemi ile toplandı.

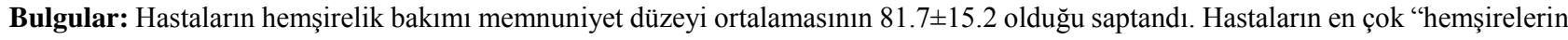
mahremiyetlerine gösterdikleri saygıdan" ve en az "hemşirelerin durumları ve tedavileri ile ilgili yeterli bilgi vermelerinden" memnun oldukları belirlendi. Hemşirelerden sağlıkla ilgili bilgi alan, hemşirelerin verdiği bilgiyi, bakımı ve iletişim düzeyini iyi bulan, korku ve endişelerini hemşirelerle paylaşan ve hemşirelerin verdiği bakımın iyileşmeye etkisinin fazla olduğunu düşünen hastaların bakım memnuniyetlerinin anlamlı şekilde daha yüksek olduğu bulundu $(\mathrm{p}<0.05)$.

Sonuç: Cerrahi hastalarının bakım memnuniyet düzeyleri ortalama puanın üzerindedir. Hastaların çoğu hemşirelerin verdiği bilginin ve bakımın yeterli olduğunu düşünürken taburculuk eğitiminin ise yeterli olmadığını düşünmektedirler. Araştırma sonuçları bakım memnuniyetini artırmak için geliştirilecek stratejilere katkı sağlayabilir.

Anahtar Sözcükler: Bakım, cerrahi hasta, memnuniyet, perioperatif hemşirelik

\section{ABSTRACT}

Objective: The study was descriptively done in order to determine nursing care satisfaction among surgical patients.

Methods: In the study, which is done with 267 patients who were treated at surgery clinics; data were collected using "a patient identification features questionnaire form" and "Newcastle satisfaction with nursing care scale" through face to face interview technique.

Results: Average nursing care satisfaction of patients was $81.7 \pm 15.2$. Patients were most satisfied with "the amount of privacy nurses gave you" and least with "the amount of information nurses gave to you about your condition and treatment". Nursing care satisfaction of patients who received information from nurses about health, found information-care-and- communication given by nurses good, shared fears and anxieties with nurses and thought that care given by nurses had bigger effect upon healing was higher and the difference among the variables was statistically significant $(\mathrm{p}<0.05)$.

Conclusion: As a result, surgery patients' care satisfactions were above the average. Besides, most of the patients thought that information and care given by nurses was enough but discharge education was not at a sufficient level. Study results may contribute to strategies will be developed in order to increase care satisfaction.

Keywords: Care, perioperative nursing, satisfaction, surgery patient

ORCID IDs of the authors: SA: 0000-0002-4997-7045; AG: 0000-0003-3585-4500

Sorumlu yazar/Corresponding author: Arş. Gör. Sibel Arslan

Kilis 7 Aralık Üniversitesi Yusuf Șerefoğlu Sağlık Bilimleri Fakültesi, Cerrahi Hastalıklar Hemșireliği Anabilim Dalı, Kilis, TÜRKIYE e-posta/e-mail: sibel.arslan@kilis.edu.tr

* Bu makale, 3. Uluslararası 11. Ulusal Türk Cerrahi ve Ameliyathane Hemşireliği Kongresi'nde poster bildiri olarak sunulmuştur.

*Bu makale, Karadeniz Teknik Üniversitesi Sağllk Bilimleri Enstitüsü Cerrahi Hastalıkları Hemşireliği Anabilim Dall Yüksek Lisans Tez çalı̧̧masından üretilmişstir.

Atıf/Citation: Arslan S, Gürsoy A. (2021). Hastaların hemşirelik bakım memnuniyetleri: cerrahi hastaları örneği. Ordu Üniversitesi Hemşirelik Çalışmaları Dergisi, 4(1), 21-28. DOI:10.38108/ouhcd.836914 


\section{Giriş}

Subjektif ve çok boyutlu bir kavram olan "memnuniyet" günümüzde hastanelerin verdikleri hizmet kalitesini değerlendirmede kullandıkları önemli bir göstergedir. Hasta memnuniyeti; hizmetin sunumu, hasta ve hizmet veren ilișkisini, hizmetin sürekliliğini ve yeterliliğini ölçen bir kavram olarak da kabul edilmektedir (Gökkaya ve ark., 2018).

Sağlık bakım hizmetinde memnuniyet; hastanın kendi bakımına katılmasında, istekli olmasında ve kendini ifade etmesinde önemli bir etkendir. Memnuniyeti her birey farklı değerlendirmekte olup, kişinin hastalığı, kişilik özellikleri, daha önce aldığı sağlık hizmeti, yaşı, psikolojik özellikleri, sosyal hayatı gibi etmenler değerlendirmede etkili olabilmektedir (Findık ve ark., 2010). Bunların yanında çalışanların hastayla iletişimi, tutum ve davranışları, hastayı bilgilendirmeleri ve yönlendirmeleri, bilgi ve becerilerini sunma yöntemleri, hastaya gösterdikleri nezaket, ilgi ve güven vermeleri gibi etkenlerde hasta memnuniyetinde önemli olan unsurlardır (Özşaker ve Kayrakçı, 2014; Uzun 2003; Yıldız ve ark., 2014).

Sağlık hizmetleri kalitesinin temel basamaklarından birini hasta memnuniyeti oluşturmaktadır. Hasta memnuniyetinin artması, hasta yatış süresinin kısalmasına, maliyetin azalmasina, hasta tatmininin artmasına ve hastanın kuruma bağlanmasına neden olur (Taşlıyan ve Akyüz, 2010).

Cerrahi işlemler ya da ameliyat; tedaviye cevap vermeyen durumlarda hastayı sağlığına kavuşturmak, hastalık bulgularını hafifletmek, işlev bozukluklarını en aza indirmek, hastalığı tanılamak ve hastanın rahat etmesini sağlamak gibi nedenlerle başvurulan tedavi yöntemlerindendir. Ameliyat, tedavi amaciyla yapılan ancak hastanın fizyolojik dengesini, doku bütünlüğünü bozan "kontrollü travma"dır (Aslan ve ark., 2018). Cerrahi hemșireleri perioperatif dönem boyunca hastaların fizyolojik, psikolojik ve kültürel ihtiyaçlarına cevap verme, sağlığını sürdürme, bakım ve tedavisini bilimsel ve kanıta dayalı olarak yapmakla yükümlüdür. Hastaya bireysel, bilimsel ve hasta ihtiyaçlarına yönelik bakım sunan hemşireler sağlık hizmetlerinin kalite güvencesinde önemli bir göreve sahiptirler (Aiken 2018).

Hasta memnuniyeti hemşirelerle ilgili birçok faktörle ilişkilendirilebilir. Hemşirelerin tecrübeleri, bilgi düzeyleri, becerileri, hekimle iş birliği içinde olmaları, çalıșma ortamları hastalar üzerindeki bakım kalitesini etkiler (Gröndahl 2019).

Sağlık sistemi içerisinde hastanın verilen bakımdan memnuniyetini belirlemek, memnuniyeti arttıracak düzenlemeler için zemin hazırlamada önem taşımaktadır. Konuya ilişkin yapılan çalışmalarda hastaların hemşirelik bakımından orta düzeyde memnun oldukları belirtilmiştir (Alan 2017; Özşaker ve Kayrakçı, 2014). Ancak sadece cerrahi hastaların memnuniyetini ölçen çalışmalar sınırlı sayıdadır. Bu gereksinimden yola çıkılarak yapılan araştırmada cerrahi hastalarının hemşirelik bakımına ilişkin memnuniyetlerini ve memnuniyeti etkileyen faktörleri belirlemek amaçlandı.

\section{Araștırmanın soruları}

1. Cerrahi hastaları hemşirelik bakımından ne kadar memnunlar?

2. Cerrahi hastalarının sosyodemografik ve sağlık durumlarına ilişkin bazı özellikleri hemşirelik bakım memnuniyetini nasıl etkilemektedir?

3. Cerrahi hastalarının hemşirelik bakımı ile ilgili görüşleri hemşirelik bakım memnuniyetini nasıl etkilemektedir?

\section{Yöntem}

Tanımlayıcı olan araştırma Marmara bölgesindeki bir ilin iki farklı eğitim ve araştırma hastanesinde gerçekleștirildi. A hastanesi 800 yatağa, B hastanesi ise 360 yatağa sahiptir. A hastanesinde ortopedi, genel cerrahi, beyin cerrahi, üroloji, plastik cerrahi kliniklerinde yatan hastalar araştırma kapsamına alındı. B hastanesinde ise kalp damar cerrahi ve gögüus cerrahi kliniklerinde yatan hastalar örnekleme dahil edildi.

Çalışmada örneklem sayısını belirlemek için OpenEpi programında güç analizi yapıldı (Dean ve ark., 2015). Benzer eğitim çalışmalarının sonuçları dikkate alınarak, $\% 90$ güven aralığında, $\% 80$ güç ile yapılan güç analizi sonucunda araştırma için 267 hastanın yeterli olacağı saptandı. Araştırma örneklemine; 18 yaş ve üzeri, Türkçe bilen, okuryazar olan, çalışma kapsamındaki cerrahi kliniklerde en az 24 saat en fazla yedi gün yatan hastalar alındı. Acil ameliyat olan, iletişim kurmaya engel bir duruma sahip ve psikiyatrik bir rahatsızlı̆ 1 ya da tedavisi olan hastalar ise örneklem dişında bırakıldı. Aralık 2017-Kasım 2018 tarihleri arasında 282 hastaya ulaşıldı, 15 'i çalışmaya katılmayı kabul etmedi ve çalışma 267 kişi ile tamamland.

Veriler Newcastle hemşirelik bakımı memnuniyet ölçeği ve araştırmacı tarafindan hazırlanan hasta tanitıcı özellikler formu kullanılarak topland1. 
Hasta Tanitıci Özellikler Formu: Araştırmacıların oluşturduğu formda sosyodemografik özellikler, hastalık ve hastane (toplam yatış süresi, yattığı klinik vb.) ve hemşirelik bakımı ile ilgili 30 soru yer almaktadır.

Newcastle Hemșirelik Bakımı Memnuniyet Ölçeği (NHBMÖ): Thomas ve arkadaşları tarafindan 1996 yılında geliştirilmiş olup (Thomas ve ark., 1996), Uzun (Uzun 2003) ve daha sonra Akın ve Erdoğan (Akın ve Erdoğan, 2007) tarafindan Türkçe'ye uyarlaması yapılmıştır. Ölçeğin kesme noktası bulunmamaktadır. Toplam puanın yüksek olması hasta memnuniyetinin de yüksek olduğunu göstermektedir.

Veri toplama öncesi beș hastayla görüşülerek anketlerin ön uygulaması yapıld1. Ön uygulama yapılan hastalar çalışma kapsamına alınmadı. Ön uygulamadan elde edilen bilgiler doğrultusunda soru formlarında gerekli düzenlemeler yapıldı. Taburculuk işlemleri öncesinde hastalara bilgi verilerek gönüllü olanlar araştırmaya alındı. Daha sonra Newcastle hemşirelik bakımı memnuniyet ölçeği ve hasta tanıtıcı özellikler soru formundaki sorular, hastaların odasında yüz yüze görüşme sırasında araştırmacı tarafından hastalara okundu ve soru-yanıt şeklinde uygulandı. Her görüşme 20-30 dakika sürdü.

\section{Bulgular}

Tablo 1'de hastaların tanıtıc1 özellikleri görülmektedir. Hastaların \%53.6's1 45-67 yaş aralığında, \%59.2'si erkek ve \%65.2'sinin eğitim durumu ortaöğretim ve altıdır. Hastaların klinik özellikleri \%21.7'si genel cerrahi kliniğinde yatmakta, \%56.2'sinin toplam yatış süresi 2-4 gün aralığ1 olarak saptanmıştır. Bununla birlikte hastaların \%59.2'si ameliyat olan hasta grubundadır ve bu hastaların ameliyat sonrası yatış süreleri $\% 53.2$ 'sinin 1-2 gün olarak bulunmuştur. Yine çalışmamıza katılan hastaların \%70.8'inin yoğun bakımda kalmadığı ve yoğun bakımda kalan hastaların \%73.1'inin bir gün süreyle yoğun bakımda kaldığ 1 görülmektedir. Ayrıca tabloda yer almamakla birlikte kat1lımciların \%44.2'sinin kronik hastalığ 1 olduğu belirlendi. Hastaların \%49.4'ü daha önce bir klinikte yattığını, \%97.0'si refakatçisinin olduğunu belirtmiştir.

Tablo 2'de hastaların hemşirelik bakımı ile ilgili görüşleri yer almaktadır. Hastaların \%55.4'ü hemşirelerin verdiği bakımı yeterli buldukları ve \%58.4'ünün hemşireler tarafından verilen bakımın iyileşmeye etkisinin "fazla" olduğunu düşündüğü bulundu. Ancak hastaların \%70.9'unun korku ve endişelerini hemşirelerle paylaşmadıkları saptandı.

Tablo 1. Hastaların tanıtıcı özellikleri $(\mathrm{n}=267)$

\begin{tabular}{|c|c|c|}
\hline Özellikler & $\mathbf{n}$ & $\%$ \\
\hline \multicolumn{3}{|l|}{ Yaş } \\
\hline $18-44$ yas & 69 & 25.8 \\
\hline $45-67$ yaş & 143 & 53.6 \\
\hline $68-85$ yaş & 55 & 20.6 \\
\hline \multicolumn{3}{|l|}{ Cinsiyet } \\
\hline Erkek & 158 & 59.2 \\
\hline Kadın & 109 & 40.8 \\
\hline \multicolumn{3}{|l|}{ Eğitim Durumu } \\
\hline Ortaögretim ve altı & 174 & 65.2 \\
\hline Lise ve üstü & 93 & 34.8 \\
\hline \multicolumn{3}{|l|}{ Klinik } \\
\hline Genel cerrahi & 58 & 21.7 \\
\hline Kalp ve damar cerrahisi & 52 & 19.5 \\
\hline Ortopedi & 50 & 18.7 \\
\hline Üroloji & 39 & 14.6 \\
\hline Beyin Cerrahisi & 28 & 10.5 \\
\hline Göğüs Cerrahisi & 21 & 7.9 \\
\hline Plastik Cerrahi & 19 & 7.1 \\
\hline \multicolumn{3}{|l|}{ Toplam yatıș süresi } \\
\hline $2-4$ gün & 150 & 56.2 \\
\hline $5-7$ gün & 117 & 43.8 \\
\hline \multicolumn{3}{|l|}{ Ameliyat olma durumu } \\
\hline Evet & 158 & 59.2 \\
\hline Hayır & 109 & 40.8 \\
\hline \multicolumn{3}{|l|}{ Yoğun bakımda kalma } \\
\hline Evet & 78 & 29.2 \\
\hline Hayır & 189 & 70.8 \\
\hline \multicolumn{3}{|l|}{$\begin{array}{l}\text { Yoğun bakımda } \\
\text { kalınan süre* }\end{array}$} \\
\hline Bir gün & 57 & 73.1 \\
\hline İki gün & 14 & 17.9 \\
\hline Üç gün & 7 & 9.0 \\
\hline \multicolumn{3}{|l|}{$\begin{array}{l}\text { Ameliyat sonrası yatış } \\
\text { süresi }\end{array}$} \\
\hline 1-2 gün & 84 & 53.2 \\
\hline 3-4 gün & 47 & 29.7 \\
\hline 5 gün ve üzeri & 27 & 17.1 \\
\hline
\end{tabular}


Tablo 2. Hastaların hemşirelik bakımı ile ilgili görüşleri $(\mathrm{n}=267)$

\begin{tabular}{|c|c|c|}
\hline Görüșler & $\mathbf{n}$ & $\%$ \\
\hline \multicolumn{3}{|c|}{$\begin{array}{l}\text { Hemşirelerin verdiği } \\
\text { bakımın niteliği }\end{array}$} \\
\hline Oldukça yeterli & 98 & 36.7 \\
\hline Yeterli & 148 & 55.4 \\
\hline Yetersiz* & 21 & 7.9 \\
\hline \multicolumn{3}{|c|}{$\begin{array}{l}\text { Hemşireler tarafindan } \\
\text { verilen bakımın iyileşmeye } \\
\text { etkisi }\end{array}$} \\
\hline Fazla & 156 & 58.4 \\
\hline Kismen & 101 & 37.8 \\
\hline Hiç & 10 & 3.7 \\
\hline \multicolumn{3}{|c|}{$\begin{array}{l}\text { Korku ve endişelerin } \\
\text { hemşirelerle paylaşılma } \\
\text { durumu** }\end{array}$} \\
\hline Evet & 50 & 26.5 \\
\hline Hayır & 134 & 70.9 \\
\hline Kismen & 5 & 2.6 \\
\hline
\end{tabular}

Tabloda verilmemekle birlikte hemșirelerin hastalara en fazla ilaç tedavisi (\%58.1), ameliyat öncesi aç kalma süresi (\%52.1) ve ayağa kalkma ve yürüme zamanına $(\% 39.3)$, ilișkin hastalara bilgi verdiği belirlendi. Hemşirelerin en az ise; tetkikler (\%4.5), taburcu olduktan sonra hastaneye gelinmesi gereken durumlar (\%8.2), taburcu olduktan sonraki kontroller (\%12.0) ve yara bakımı (pansuman sıklığı, kanama, akıntı) (\%17.6) konularında bilgi verdikleri saptandi.

Tablo 3'te hastaların Newcastle hemşirelik bakımı memnuniyet ölçeğindeki maddelere verdikleri yanıtların dağılımı görülmektedir. Hastaların hemşirelik bakımı memnuniyet düzey puan ortalamasının $81.7 \pm 15.2$ olduğu belirlendi. Araştırma kapsamına alınan hastaların \%61.4'ünün hemşirelerin mahremiyete gösterdikleri saygıdan "tamamen memnun" oldukları saptandı. Tamamen memnun olunan maddeler arasında en düşük yüzdenin ise "hemşirelerin size durumunuz ve tedavinizle ilgili yeterli bilgi vermelerinden" maddesi olduğu bulundu (\%30.3).

Tablo 3. Hastaların Newcastle hemşirelik bakımı memnuniyet ölçeğindeki maddelere verdikleri yanıtlar

\begin{tabular}{|c|c|c|c|c|c|c|c|c|c|c|}
\hline \multirow[t]{2}{*}{ Maddeler } & \multicolumn{2}{|c|}{$\begin{array}{l}\text { Hiç } \\
\text { memnun } \\
\text { değilim }\end{array}$} & \multicolumn{2}{|c|}{$\begin{array}{l}\text { Nadiren } \\
\text { memnunum }\end{array}$} & \multicolumn{2}{|c|}{ Memnunum } & \multicolumn{2}{|c|}{$\begin{array}{l}\text { Çok } \\
\text { memnunum }\end{array}$} & \multicolumn{2}{|c|}{$\begin{array}{l}\text { Tamamen } \\
\text { memnunum }\end{array}$} \\
\hline & $\mathbf{n}$ & $\%$ & $\mathbf{n}$ & $\%$ & $\mathbf{n}$ & $\%$ & $\mathbf{n}$ & $\%$ & $\mathbf{n}$ & $\%$ \\
\hline 1. Hemşirelerin size ayırdığı zamanın miktarından & 5 & 1.9 & 14 & 5.2 & 80 & 30.0 & 84 & 31.5 & 84 & 31.5 \\
\hline 2. Hemşirelerin işlerindeki becerikliliğinden & 4 & 1.5 & 5 & 1.9 & 52 & 19.5 & 96 & 36.0 & 110 & 41.2 \\
\hline $\begin{array}{l}\text { 3. Her an sizinle ilgilenecek bir hemşirenin yakınınızda } \\
\text { bulunmasından }\end{array}$ & 8 & 3.0 & 10 & 3.7 & 55 & 20.6 & 88 & 33.0 & 106 & 39.7 \\
\hline $\begin{array}{l}\text { 4. Hemşirelerin sizin bakımınızla ilgili sahip oldukları bilgi } \\
\text { düzeyinden }\end{array}$ & 8 & 3.0 & 10 & 3.7 & 61 & 22.8 & 95 & 35.6 & 93 & 34.8 \\
\hline 5. Çağırdığınızda hemşirelerin hemen gelmelerinden & 6 & 2.2 & 5 & 1.9 & 48 & 18.0 & 99 & 37.1 & 109 & 40.8 \\
\hline 6. Hemşirelerin sizin kendi evinizdeymiş gibi hissettirmelerinden & 5 & 1.9 & 17 & 6.4 & 54 & 20.2 & 89 & 33.3 & 102 & 38.2 \\
\hline $\begin{array}{l}\text { 7. Hemşirelerin size durumunuz ve tedavinizle ilgili yeterli bilgi } \\
\text { vermelerinden }\end{array}$ & 16 & 6.0 & 21 & 7.9 & 54 & 20.2 & 95 & 35.6 & 81 & 30.3 \\
\hline $\begin{array}{l}\text { 8. Hemşirelerin iyi olup olmadığınızı yeterli sıklıkta kontrol } \\
\text { etmelerinden }\end{array}$ & 7 & 2.6 & 14 & 5.2 & 50 & 18.7 & 90 & 33.7 & 106 & 39.7 \\
\hline 9. Hemşirelerin size yardımcı olmalarından & 6 & 2.2 & 10 & 3.7 & 41 & 15.4 & 90 & 33.7 & 120 & 44.9 \\
\hline 10. Hemşirelerin size açıklama yapma biçiminden & 11 & 4.1 & 10 & 3.7 & 48 & 18.0 & 83 & 31.1 & 115 & 43.1 \\
\hline 11. Hemşirelerin akraba ve arkadaşlarınızı rahatlatma biçiminden & 13 & 4.9 & 10 & 3.7 & 57 & 21.3 & 86 & 32.2 & 101 & 37.8 \\
\hline 12. Hemşirelerin islerini yapma konusundaki tutumlarından & 1 & 0.4 & 7 & 2.6 & 43 & 16.1 & 106 & 39.7 & 110 & 41.2 \\
\hline $\begin{array}{l}\text { 13. Hemşirelerin durumunuz ve tedavinizle ilgili olarak size } \\
\text { verdikleri bilginin yeterliliğinden }\end{array}$ & 11 & 4.1 & 15 & 5.6 & 46 & 17.2 & 105 & 39.3 & 90 & 33.7 \\
\hline 14. Hemşirelerin size önemli bir insan gibi davranmalarından & 7 & 2.6 & 9 & 3.4 & 35 & 13.1 & 86 & 32.2 & 130 & 48.7 \\
\hline 15. Hemşirelerin endişe ve korkularınızı dinleme biçiminden & 15 & 5.6 & 10 & 3.7 & 51 & 19.1 & 82 & 30.7 & 109 & 40.8 \\
\hline 16. Serviste size tanınan serbestliğin miktarından & 2 & 0.7 & 10 & 3.7 & 43 & 16.1 & 88 & 33.0 & 124 & 46.4 \\
\hline $\begin{array}{l}\text { 17. Hemşirelerin sizin bakımınız ve tedaviniz ile ilgili } \\
\text { isteklerinize gönüllü yanıt vermelerinden }\end{array}$ & 2 & 0.7 & 7 & 2.6 & 34 & 12.7 & 93 & 34.8 & 131 & 49.1 \\
\hline 18. Hemşirelerin mahremiyetinize gösterdikleri saygıdan & - & - & 3 & 1.1 & 27 & 10.1 & 73 & 27.3 & 164 & 61.4 \\
\hline $\begin{array}{l}\text { 19. Hemşirelerin sizin bakımınız ve tedaviniz ile ilgili } \\
\text { gereksinimlerinizin farkında olmalarından }\end{array}$ & 1 & 0.4 & 7 & 2.6 & 26 & 9.7 & 93 & 34.8 & 140 & 52.4 \\
\hline
\end{tabular}


Hastaların bazı özelliklerine göre Newcastle hemşirelik bakımı memnuniyet ölçeği puan ortancalarının dağılımı Tablo 4'de yer almaktadır. Toplam yatış süresi, yoğun bakımda yatma ve yoğun bakımda yatılan süreye göre hastaların NHBMÖ ortanca değerleri arasında anlamlı farklılık olduğu $(\mathrm{p}<0.05)$ saptand1.

Tablo 4. Hastaların Newcastle hemşirelik bakımı memnuniyet ölçeği puan ortancalarının dağılımı $(\mathrm{n}=267)$

\begin{tabular}{|c|c|c|}
\hline \multirow[t]{2}{*}{ Özellikler } & \multicolumn{2}{|c|}{ NHBMÖ } \\
\hline & Ortanca (Min- Max) & $\begin{array}{c}\text { İstatiksel Analiz } \\
\text { P }\end{array}$ \\
\hline \multicolumn{3}{|l|}{ Yaş } \\
\hline $18-44$ yaş & $87.3(31.5-100.0)$ & \multirow{3}{*}{$\begin{array}{c}\mathrm{KW}=0.638 \\
\mathrm{p}=0.727\end{array}$} \\
\hline $45-67$ yaş & $79.4(79.4-100.0)$ & \\
\hline $68-85$ yaş & $80.5(43.1-100.0)$ & \\
\hline \multicolumn{2}{|l|}{ Cinsiyet } & \multirow{3}{*}{$\begin{array}{c}U=7941.500 \\
p=0.280\end{array}$} \\
\hline Kadın & $80.0(23.1-100.0)$ & \\
\hline Erkek & $84.2(43.1-100.0)$ & \\
\hline \multicolumn{2}{|l|}{ Eğitim Durumu } & \multirow{3}{*}{$\begin{array}{c}\mathrm{U}=7700.500 \\
\mathrm{p}=0.515\end{array}$} \\
\hline $\begin{array}{l}\text { Ortaögretim ve } \\
\text { alt1 }\end{array}$ & $84.2(23.1-100.0)$ & \\
\hline Lise ve üstü & $81.0(38.9-100.0)$ & \\
\hline \multicolumn{2}{|l|}{ Klinik } & \multirow{9}{*}{$\begin{array}{c}\mathrm{KW}=10.671 \\
\mathrm{p}=0.099\end{array}$} \\
\hline Genel Cerrahi & $76.8(23.1-100.0)$ & \\
\hline Kalp ve Damar & $90.5(47.3-100.0)$ & \\
\hline Cerrahi & & \\
\hline Ortopedi & $82.6(43.1-100.0)$ & \\
\hline Üroloji & $81.0(50.5-100.0)$ & \\
\hline Beyin Cerrahi & $80.5(31.5-100.0)$ & \\
\hline Göğüs Cerrahi & $83.1(46.3-100.0)$ & \\
\hline Plastik Cerrahi & $85.2(75.7-100.0)$ & \\
\hline \multicolumn{2}{|l|}{$\begin{array}{l}\text { Toplam yatış } \\
\text { süresi }\end{array}$} & \multirow{3}{*}{$\begin{array}{c}\mathrm{U}=3602.500 \\
\mathbf{p}<\mathbf{0 . 0 0 1}\end{array}$} \\
\hline 2-4 gün & $80.5(43.1-100.0)$ & \\
\hline 5-7 gün & $85.2(23.1-100.0)$ & \\
\hline \multicolumn{2}{|l|}{$\begin{array}{l}\text { Ameliyat olma } \\
\text { durumu }\end{array}$} & \multirow{3}{*}{$\begin{array}{c}\mathrm{U}=7547.000 \\
\mathrm{p}=0.086\end{array}$} \\
\hline Evet & $85.2(23.1-100.0)$ & \\
\hline Hayır & $80.0(46.3-100.0)$ & \\
\hline \multicolumn{2}{|l|}{$\begin{array}{l}\text { Yoğun bakımda } \\
\text { yatma }\end{array}$} & \multirow{3}{*}{$\begin{array}{c}U=6064.000 \\
\mathbf{p}=\mathbf{0 . 0 2 3}\end{array}$} \\
\hline Evet & $89.4(47.3-100.0)$ & \\
\hline Hayır & $80.0(23.1-100.0)$ & \\
\hline \multicolumn{2}{|c|}{ Yoğun bakımda yatılan süre $(n=78)$} & \multirow{4}{*}{$\begin{array}{c}\mathrm{KW}=7.145 \\
\mathbf{p}=\mathbf{0 . 0 2 8}\end{array}$} \\
\hline Bir gün & $92.6(47.3-100.0)$ & \\
\hline İki gün & $77.3(48.4-100.0)$ & \\
\hline Üç gün & $76.8(65.2-95.7)$ & \\
\hline \multicolumn{2}{|l|}{ Kronik hastalık } & \multirow{3}{*}{$\begin{array}{c}\mathrm{U}=8562.000 \\
\mathrm{p}=0.714\end{array}$} \\
\hline Var & 84.7 (43.1-100.0) & \\
\hline Yok & $81.0(23.1-100.0)$ & \\
\hline \multicolumn{2}{|l|}{ Refakatçi } & \multirow{3}{*}{$\begin{array}{c}\mathrm{U}=967.000 \\
\mathrm{p}=0.748\end{array}$} \\
\hline Var & $83.1(23.1-100.0)$ & \\
\hline Yok & $82.1(43.1-100.0)$ & \\
\hline \multicolumn{2}{|l|}{$\begin{array}{l}\text { Daha önce } \\
\text { cerrahi klinikte } \\
\text { yatma }\end{array}$} & \multirow[t]{3}{*}{$\begin{array}{c}\mathrm{U}=7846.000 \\
\mathrm{p}=0.091\end{array}$} \\
\hline Evet & $80.0(38.9-100.0)$ & \\
\hline Hayır & $85.2(23.1-100.0)$ & \\
\hline $\begin{array}{l}\text { Ameliyat sonra } \\
\mathrm{n}=158\end{array}$ & hastanede yatış süresi & \\
\hline 1-2 gün & $88.9(43.1-100.0)$ & $K W=2.423$ \\
\hline 3-4 gün & $81.0(23.1-100.0)$ & $\mathrm{p}=0.298$ \\
\hline 5 gün ve üzeri & $80.0(38.9-100.0)$ & \\
\hline
\end{tabular}

Hastaların hemşirelik bakımı ile ilgili görüşlerine göre Newcastle hemşirelik bakımı memnuniyet ölçeği puan ortancalarının dağılımı Tablo 5'de yer almaktadır. Hemşirelerden sağlıkla ilgili bilgi alma, hemşirelerin verdiği bilginin ve bakımın niteliğgi, iletişim düzeyi, korku ve endişelerin hemşirelerle paylaşılma durumu ve bakımın iyileşmeye etkisi ile ilgili hasta görüşleri konusunda hastaların NHBMÖ ortanca değerlerinde anlamlılık olduğu belirlendi $(\mathrm{p}<0.05)$.

Tablo 5. Bakım ile ilgili Newcastle hemşirelik bakımı memnuniyet ölçeği puan ortancalarının dağ $111 \mathrm{~m} 1(n=267)$

\begin{tabular}{|c|c|c|}
\hline \multirow[b]{2}{*}{ Görüşler } & \multicolumn{2}{|c|}{ NHBMÖ } \\
\hline & $\begin{array}{l}\text { Ortanca (Min- } \\
\text { Max) }\end{array}$ & $\begin{array}{l}\text { İstatistiksel } \\
\underset{\mathbf{P}}{\text { analiz }}\end{array}$ \\
\hline \multicolumn{3}{|c|}{$\begin{array}{l}\text { Hemşirelerden sağlıkla ilgili } \\
\text { bilgi alma durumu }\end{array}$} \\
\hline Evet & $87.3(46.3-100.0)$ & $\mathrm{U}=3602.500$ \\
\hline Hayır & $75.2(23.1-100.0)$ & $\mathbf{p}<0.001$ \\
\hline \multicolumn{3}{|c|}{$\begin{array}{l}\text { Hemşirelerin verdiği } \\
\text { bilgilerin düzeyi }\end{array}$} \\
\hline $\begin{array}{l}\text { Oldukça yeterli } \\
\text { Yeterli } \\
\text { Yetersiz* }\end{array}$ & $\begin{array}{l}96.8(57.8-100.0) \\
83.1(46.3-100.0) \\
75.2(23.1-100.0)\end{array}$ & $\begin{array}{c}\mathrm{KW}=54.865 \\
\mathbf{p}<\mathbf{0 . 0 0 1}\end{array}$ \\
\hline \multicolumn{2}{|c|}{$\begin{array}{l}\text { Hemşirelerin iletişim } \\
\text { düzeyi }\end{array}$} & \\
\hline $\begin{array}{l}\text { Oldukça yeterli } \\
\text { Yeterli } \\
\text { Yetersiz* }\end{array}$ & $\begin{array}{l}95.7(47.3-100.0) \\
78.4(43.1-100.0) \\
60.0(23.1-85.2)\end{array}$ & $\begin{array}{c}\mathrm{KW}=67.151 \\
\mathbf{p}<\mathbf{0 . 0 0 1}\end{array}$ \\
\hline \multicolumn{3}{|c|}{$\begin{array}{l}\text { Hemşirelerin verdiği } \\
\text { bakımın niteliği }\end{array}$} \\
\hline $\begin{array}{l}\text { Oldukça yeterli } \\
\text { Yeterli } \\
\text { Yetersiz* }\end{array}$ & $\begin{array}{l}94.7(48.4-100.0) \\
77.8(38.9-100.0) \\
61.0(23.1-97.8)\end{array}$ & $\begin{array}{c}\mathrm{KW}=77.8 \\
\mathbf{p}<\mathbf{0 . 0 0 1}\end{array}$ \\
\hline \multicolumn{3}{|c|}{$\begin{array}{l}\text { Korku ve endişelerin } \\
\text { hemşirelerle paylaşılma } \\
\text { durumu }\end{array}$} \\
\hline $\begin{array}{l}\text { Evet } \\
\text { Hayır } \\
\text { Kismen }\end{array}$ & $\begin{array}{l}88.9(46.3-100.0) \\
80.0(23.1-100.0) \\
70.5(53.6-78.9)\end{array}$ & $\begin{array}{c}\mathrm{KW}=7.825 \\
\mathbf{p}=\mathbf{0 . 0 2 0}\end{array}$ \\
\hline \multicolumn{3}{|c|}{$\begin{array}{l}\text { Hemşireler tarafından } \\
\text { verilen bakımın } \\
\text { iyileșmeye etkisi }\end{array}$} \\
\hline $\begin{array}{l}\text { Fazla } \\
\text { Kısmen } \\
\text { Hiç }\end{array}$ & $\begin{array}{l}91.0(46.3-100.0) \\
75.7(23.1-100.0) \\
63.1(43.1-80.0)\end{array}$ & $\begin{array}{c}\mathrm{KW}=61.681 \\
\mathbf{p}<\mathbf{0 . 0 0 1}\end{array}$ \\
\hline \multicolumn{3}{|c|}{$\begin{array}{l}\text { Daha önce yatılan cerrahi } \\
\text { kliniklerdeki hemşirelik } \\
\text { bakımından memnuniyet durumu }\end{array}$} \\
\hline $\begin{array}{l}\text { Oldukça yeterli } \\
\text { Yeterli } \\
\text { Yetersiz* }\end{array}$ & $\begin{array}{l}80.0(43.1-100.0) \\
82.6(38.9-100.0) \\
77.6(47.3-100.0)\end{array}$ & $\begin{array}{c}\mathrm{KW}=3.249 \\
\mathrm{p}=0.197\end{array}$ \\
\hline
\end{tabular}




\section{Tartışma}

Sağlık sisteminde hasta bakım memnuniyetini değerlendirmek ve sonuçlardan yararlanmak memnuniyeti arttırmak için yapılacak düzenlemelere katkı sağlamaktadır.

$\mathrm{Bu}$ amaçla yapılan araştırmaya katılan hastaların dörtte üçünün hemşirelerden bilgi aldıkları ve çoğunluğunun hemşirelerin verdiği bilgi düzeyini, hemşirelerin iletişim düzeyini ve verdiği bakımın niteliğini "yeterli ve oldukça yeterli" olarak tanımladıkları saptandı. Hastaların yarısından fazlası hemşireler tarafından verilen bakımın iyileşmeye etkisinin "fazla" olduğunu düşünmekte ancak yaklaş1k dörtte biri korku ve endişelerini hemşirelerle paylaşabildiğini ifade etmektedir. Yapılan araştırmalarda da çalışmamıza benzer olarak hastaların hemşirelerden bilgi aldıkları (Öztürk ve ark., 2011; Savaş ve Bahar, 2011), hemşirelerin iletişiminin yeterli olduğunu düşündükleri (Özşaker ve Kayrakçı, 2014; Savaş ve Bahar, 2011) ve verdikleri bakım hakkında olumlu görüşe sahip oldukları belirlenmiştir (Sillero ve Zabalegui, 2018). Çalışmamıza göre hastaların çoğunun hemşirelerden bilgi alması, hemşirelerin verdiği bakım ve iletişim düzeyleri hakkında olumlu görüşe sahip olmaları sevindirici bir sonuçtur, ancak korku ve endişelerini hemşirelerle paylaşamamalarının nedenlerinin araştırılması gerekmektedir.

Çalışmamızda hemşirelerin en çok; ilaç tedavisi, ameliyat öncesi aç kalma süresi, ayağa kalkma ve yürüme zamanı, ameliyat öncesi tüy temizliği ve beslenme konularında hastalara bilgi verdikleri saptand1. En az olarak; tetkikler, taburcu olduktan sonra hastaneye gelinmesi gereken durumlar, kontroller ve yara bakımı olduğu belirlendi. Yapılan bir çalışmada hemşirelerin; beslenme, hareket ve ilaç konularında daha fazla ve taburculuk sonrası evde bakım uygulamaları hakkında daha az eğitim verdikleri saptanmıştır (Öztürk ve ark., 2011). Başka bir çalışmada hemşirelerin dörtte üçünün ameliyat öncesi dönemde hastalara eğitim verdikleri, ancak derin solunum ve öksürük, ekstremite ve dönme egzersizlerine ilişkin eğitime yer vermedikleri belirlenmiştir (Özdelikara ve ark., 2013). Hemşireler tarafından verilen perioperatif dönemdeki hasta eğitimlerinde eksikliklerin olduğu görülmektedir.

Çalışmaya katılan hastaların NHBMÖ puan ortalaması $81.7 \pm 15.2$ 'dir. Çalışmamıza benzer olarak cerrahi kliniklerinde yapılan diğer çalışmalarda puan ortalamaları 62.3 ile 76.5 arasında değişmektedir (Aldemir ve ark., 2018;
Kersu ve ark., 2020; Özşaker ve Kayrakçı, 2014; Şendir ve ark., 2012). Hastaların en çok "hemşirelerin mahremiyete gösterdikleri saygıdan" memnun oldukları belirlendi. Yapılan araştırmalarda da çalışmamıza benzer olarak "hemşirelerin mahremiyetlerine sayg1 gösterme durumları" en yüksek memnuniyet puanını almıştır (Kuzu ve Ulus, 2014; Köseoğlu ve Seki, 2020; Özşaker ve Kayrakçı, 2014; Şişe ve Altınel, 2012). Hastaların en az memnun oldukları bakım girişimi ise; hemşirelerin durumları ve tedavileri ile ilgili yeterli bilgi vermeleridir. Çalışmamıza paralel olarak hastaların en az memnun oldukları konuların hemşirelerin kendilerine durumları ve tedavileri ile ilgili yeterli bilgi vermemeleri, kendilerine zaman ayırmamaları ve kendilerinin bakımları ile ilgili sahip oldukları bilgi düzeyini yeterli bulmaları olduğu belirlenmiştir (Özşaker ve Kayrakçı, 2014). Çalışmamızdan farklı olarak yapılan çalışmalarda "hemşirelerin hastaları kendi evlerinde gibi hissettirmeleri" maddesi hastaların en az memnun oldukları durum olarak belirlenmiştir (Kuzu ve Ulus, 2014; Köseoğlu ve Seki, 2020). Yapılan çalışmalara göre hastaların hemşirelerden bilgi alma konusunda istekli oldukları görülmektedir. Ancak bilgi vermeye ilişkin memnuniyetin düşük olmasının nedenlerinin araştırılması gerekmektedir.

Hastaların sosyodemografik özelliklerinin memnuniyeti etkileyen anlamlı değişkenler olmadığ 1 saptand1. Literatür incelendiğinde çalışmamıza benzer olarak yaşın memnuniyeti etkileyen değişken olmadığını belirten araştırmalar mevcuttur (Kuzu ve Ulus, 2014; Şișe ve Altınel, 2012). Bunun yanı sıra çalışmamızla benzer olarak eğitim seviyesi düşük olanların hemşirelik bakım memnuniyetinin yüksek olduğunu belirten araştırmalarda yer almaktadır (Alan 2017; Cerit 2015; Demir ve ark., 2011; Kuzu ve Ulus, 2014; Köseoğlu ve Seki, 2020; Sillero ve Zabalegui, 2018; Şişe ve Altınel, 2012). Bazı çalışmalar eğitim düzeyinin memnuniyeti etkilemeyen değişken olduğunu belirtirken (Demir ve ark., 2011; Köseoğlu ve Seki, 2020; Oğuzalp ve ark., 2010; Sayın ve ark., 2016), etkilendiğini bulan çalışmalar da mevcuttur (Alan 2017; Kuzu ve Ulus, 2014). Eğitim seviyesi düşük hastaların hemşirelerden daha az beklenti içerisinde olmalarından dolayı bakım memnuniyetlerinin daha fazla olduğu düşünülebilir.

Çalışmamızda hastanede kalış süresi daha uzun olan hastaların hemşirelik bakım memnuniyet düzeyi yatış süresi kısa olanlara göre anlamlı şekilde yüksektir. Yatış süresi uzadıkça, hasta hemşirelik bakım hizmetleri ile daha çok karşılaşmaktadır. 
Ayrıca yatış süresi kısaldıkça hastalar ile hemşireler arasında güvene dayalı iletişim kurma şansı azalmaktadır. Hasta memnuniyeti ile yatış süresi arasındaki doğru orantı bu etkenlere dayalı olabilir. Yapılan çalışmalarda yatış süresinin memnuniyeti etkilediği ortak sonuç olarak belirlenmiştir (Alan 2017; Sharew ve ark., 2018). Başka bir çalışmada ise hastanede yatış süresinin memnuniyet düzeyi ile anlamlı bir ilişki durumu olmadığı ancak yatış süresi uzun olan hastaların memnuniyet puanlarının daha yüksek olduğu bulunmuştur (Köseoğlu ve Seki, 2020). Yine yoğun bakımda yatan hastaların yatmayanlara göre memnuniyet düzeyleri daha yüksektir. Yoğun bakımda kalma durumunun hastanın yaşam aktivitelerini etkilemesi ve refakatçileri olmadığı için ihtiyaç duydukları bakımı hemşirelerden almalarından dolayı hemşirelik bakım memnuniyetlerinin daha yüksek olduğu düşünülmektedir. Yoğun bakımda daha kısa süre kalan hastaların uzun süre kalanlara göre bakım memnuniyetlerinin anlamlı şekilde daha yüksek olduğu belirlendi. Yoğun bakımda fazla kalan hastalarda yoğun bakım şartlarından (mahremiyet duygusu, cihazların sesi, ortamın sıcaklığı, refakatçi olmaması vb.) kaynaklı olarak memnuniyetin azaldığı düşünülebilir.

Araştırmamızda hemşireleri bilgi verme, bakım ve iletişim kurma yönünden yeterli bulan, korku ve endişelerini hemşirelerle paylaşan hastaların bakım memnuniyetlerinin daha yüksek olduğu belirlendi. Çalışmamıza paralel olarak başka bir çalışmada hemşirelerin iletişimini ve bakımını yeterli bulan hastaların memnuniyetlerinin daha yüksek olduğu saptanmıştır (Özşaker ve Kayrakçı, 2014). Hemşirelerden yeterli bilgi ve bakım alabilen, hemşirelerle etkili iletişim kurabilen ve korku ve endişelerini hemşirelerle paylaşabilen hastaların hemşirelik bakım memnuniyetinin daha yüksek olması beklenen bir durumdur. $\mathrm{Bu}$ sonuçlar hemşirelerin hasta üzerindeki etkilerinin önemini güçlendirmektedir. Ayrıca hemşirenin verdiği bakımın ve eğitimin hasta üzerinde olumlu gelişmelere yol açması hemşirelerde mesleki doyumu ve sahada araştırmalar yapılmasını sağlayabilir.

Çalışmamızda daha önceki cerrahi klinikte yatma deneyiminin bakım memnuniyetini etkilemediği saptand. Başka bir çalışmada ise hastaların ameliyat deneyimi ile hemşirelik bakım memnuniyet arasında istatistiksel olarak anlamlı bir fark bulunmamıştır (Kersu ve ark., 2020). Hemşirelerin hastalara verdikleri bakımın etkinliği hastaların cerrahi deneyiminden ziyade hastaların mevcut durumlarını iyileştirmeyle ilgili olduğu düşünülebilir.

\section{Sonuc}

Elde edilen sonuçlara göre hastaların hemşirelik bakımı memnuniyet düzey puan ortalamasının yüksek olduğu saptandı. Hastaların sahip oldukları bireysel ya da sağlı durumları ile ilgili birçok özellik memnuniyetleri etkilememektedir. Ancak hemşireden bilgi alan, verilen bilgi ve bakımı yeterli bulan hastaların memnuniyetleri yüksektir.

$\mathrm{Bu}$ doğrultuda hemşirelerin etkin hasta eğitimi yapmalarını engelleyen etmenler ve çözüm önerileri ile ilgili araştırmalar yapılmalı ve stratejiler geliştirilmelidir. Yine hasta-hemşire iletişim sorunlarını azaltmak için iletişim tekniklerine yönelik çözümler (drama eğitimleri, iletişim atölyeleri) geliştirilmelidir. Sağlık kurumlarının kendilerini değerlendirmek için memnuniyet çalışmalarının belli aralıklarla tekrarlanması ve memnun olunmayan durumların iyileştirilmesi için yol haritaları belirlenmesi önerilir.

\section{Araştırmanın Etik Yönü/ Ethics Committee Approval: Yasal İzin ve Etik Kurul Onayı \\ Araştırma için Karadeniz Teknik Üniversitesi Tıp Fakültesi Bilimsel Araştırmalar Etik Kurul Başkanlığı'ndan 28.06.2017 tarihinde etik kurul izni (Sayı: 24237859-617) alınd1. Bunun yanı sıra araştırmanın yapılacağı hastanelerden kurum izni alındı. Ayrıca araştırma hakkında hastalara bilgi verilerek, gönüllü hasta onam formu ile çalışmaya katılmaları için onayları alınd1.}

Hakem/Peer-review: Diş hakem değerlendirmesi.

Yazar Katkısı/Author Contributions: Fikir/kavram: AG, SA; Tasarım: AG, SA; Danışmanlık: AG; Veri toplama: SA; Veri işleme: SA; Analiz ve/veya Yorum AG, SA; Kaynak tarama: AG, SA; Makalenin Yazımı: AG, SA; Eleştirel inceleme: AG

Çıkar çatışması/Conflict of interest: Araştırmamızda çıkar çatışması yoktur.

Finansal Destek/Financial Disclosure: Yazarlar araştırma için hiçbir kurumdan finansal destek almamıştır.

\section{Çalışma Literatüre Ne Kattı?}

- Bu çalışma cerrahi hastalarının hemşirelik bakımına yönelik görüşlerini belirtmektedir.

- Cerrahi servislerde hemşirelik bakımında etkin olabilecek sonuçlar hemşireler için yol gösterici olabilir. 


\section{Kaynaklar}

Aiken LH, Sloane DM, Ball J, Bruyneel L, Rafferty AM, Griffiths P. (2018). Patient satisfaction with hospital care and nurses in England: an observational study. BMJ Open Access, 8, e019189.

Akın S, Erdoğan S. (2007). The Turkish version of the Newcastle satisfaction with nursing care used on medical and surgical patients. Journal of Clinical Nursing, 16, 646-653.

Alan H. (2018). Bir üniversite hastanesinde yatan hastaların hemsirelik hizmetlerinden memnuniyet düzeyleri. Hemşirelikte Eğitim ve Araştırma Dergisi, 15(2), 81-87.

Aldemir K, Gürkan A, Yılmaz FT, Karabey G. (2018). Cerrahi kliniklerde yatan hastaların hemşirelik bakımından memnuniyetinin incelenmesi. Sağlık ve Hemşirelik Yönetimi Dergisi, 5(3), 155-163.

Aslan FE, Şahin SK, Secginli S, Bülbüloğlu S. (2018). Hastaların, ameliyat sonrası ağrı yönetimine ilişkin hemşirelik uygulamalarından memnuniyet düzeyleri: Bir sistematik derleme. Ağrı Dergisi, 30(3), 105-115.

Cerit B. (2015). Hastaların hemşirelik bakımından memnuniyet düzeyi. Hacettepe Üniversitesi Hemşirelik Fakültesi Dergisi, 3(1), 27-36.

Dean AG, Sullivan KM, Soe MM. (2015). OpenEpi: open source epidemiologic statistics for public health, version. Erişim tarihi: 10.04.2017, www.OpenEpi.com

Demir Y, Arslan GG, Eşer İ, Khorshıd L. (2011). Bir eğitim hastanesinde hastaların hemşirelik hizmetlerinden memnuniyet düzeylerinin incelenmesi. İstanbul Üniversitesi Florence Nightingale Hemşirelik Dergisi, 19(2), 68-76.

Findık UY, Unsar S, Sut N. (2010). Patient satisfaction with nursing care and its relation ship with patient characteristics. Nursing and Health Sciences, 12(2), 162- 169.

Gökkaya D, İzgüden D, Erdem R. (2018). Şehir hastanesinde hasta memnuniyeti araştırması: Isparta ili örneği. Süleyman Demirel Üniversitesi Vizyoner Dergisi, 9(20), 136-148.

Gröndahl W, Muurinen H, Katajisto J, Suhonen R, LeinoKilpi H. (2019). Perceived quality of nursing care and patient education: a cross-sectional study of hospitalised surgical patients in Finland. BMJ Open Access, 9, e023108.

Kersu Ö, Boğa SM, Köşgeroğlu N, Sayılan AA, İlter G, Baydemir C. (2020). Cerrahi servislerinde yatan hastaların hemşirelik bakım kalitesi algılamaları ile memnuniyet durumları arasındaki ilişkinin belirlenmesi. Koç Üniversitesi Hemşirelikte Eğitim ve Araştırma Dergisi, 17(1), 32-39.

Kuzu C, Ulus B. (2014). Cerrahi kliniklerde tedavi gören hastaların aldıkları hemșirelik bakımından memnuniyet durumlarının belirlenmesi. Acıbadem Üniversitesi Sağlık Bilimleri Dergisi, 5(2), 129-134.

Köseoğlu Ş, Seki Z. (2020). Genel cerrahi servisinde yatan hastaların batın ameliyatı sonrası hemşirelik bakımına ilişkin memnuniyet düzeylerinin belirlenmesi. Yoğun Bakım Hemşireliği Dergisi, 24(2), 121-133.

Oğuzalp H, Pamuk AG, Turgay Ö. (2010). Günübirlik cerrahide ebeveyn anksiyetesinin ve beklentilerinin değerlendirilmesi. Türk Anestezi ve Reanimasyon Dergisi, 38(3), 208-216.

Özdelikara A, Tan M, Polat H. (2013). Hasta öğrenim gereksinimlerinin belirlenmesi. Florence Nightingale Hemşirelik Dergisi, 21(1), 1-8.

Özşaker E, Kayrakçı F. (2014). Cerrahi hastalarının hemşirelik bakımından memnuniyet düzeylerinin belirlenmesi. İstanbul Üniversitesi Florence Nightingale Hemşirelik Dergisi, 22(2), 105-113.

Öztürk H, Çilingir D, Hintistan S. (2011). Hastaların dahiliye ve cerrahi kliniklerinde hemşirelerin yaptığı hasta eğitimlerini değerlendirmesi. Dokuz Eylül Üniversitesi Hemşirelik Yüksek Okulu Elektronik Dergisi, 4(4), 153-158.

Savaş E, Bahar A. (2011). Gaziantep Üniversitesi Tip Fakültesi Hastanesinde yatan hastaların memnuniyet düzeylerinin belirlenmesi. Gaziantep Tip Dergisi, 17(1), 24-28.

Sayın Y, Cengiz HÖ, Ayoğlu T. (2016). Nursing care satisfaction of surgery patients. SOJ Nur Health Care, 2(2), 1-8.

Sharew NT, Bizuneh HT, Assefa HK, Habtewold TD. (2018). Investigating admitted patients' satisfaction with nursing care at Debre Berhan Referral Hospital in Ethiopia: a cross-sectional study. BMJ Open 8(5): 1-8.

Sillero AS, Zabalegui A. (2018). Satisfaction of surgical patients with perioperative nursing care in a Spanish tertiary care hospital. SAGE Open Medicine, 6, 1-9.

Şendir M, Büyükyılmaz F, Yazgan İ, Bakan N, Mutlu A, Tekin F. (2012). Ortopedi ve travmatoloji hastalarının hemşirelik bakımına ilişkin deneyim ve memnuniyetlerinin değerlendirilmesi. Florence Nightingale Hemşirelik Dergisi, 20(1), 35-42.

Şişe Ş, Altınel EC. (2012). Bir üniversite hastanesinde yatan hasta memnuniyeti. Selçuk Tıp Dergisi, 28(4), 213-218.

Taşlıyan M, Akyüz M. (2010). Sağlık hizmetlerinde hasta memnuniyet araştırmasi: Malatya Devlet Hastanesi'nde bir alan çalışması. KMÜ Sosyal ve Ekonomik Araştırmalar Dergisi, 12(19), 61-66.

Thomas LH, McColl E, Priest J, Bond S, Boys JR. (1996). Newcastle satisfaction with nursing scales: an instrument for qualityassessments of nursing care. Quality Health Care, 5(2), 67-72.

Uzun Ö. (2003). Hemşirelik bakım kalitesi ile ilgili Newcastle Memnuniyet Ölçeği'nin Türkçe formunun geçerlilik ve güvenirliliğinin saptanması. Türk Hemşireler Dergisi, 54(2), 16-24.

Yıldız T, Önler E, Başkan B, Koluaçık B, Malak A, Özdemir A ve ark. (2014). Cerrahi birimlerde yatan hastaların hemşirelik hizmetlerinden memnuniyet düzeyinin belirlenmesi. International Journal Basic and Clinnical Medicine, 2(3), 123-130. 